\title{
Part V: Place Names
}

Place names can provide information about hostages that cannot be obtained from other sources. In his study of sacred place names in the provinces around Lake Mälaren in present Sweden, Vikstrand points out that these names reflect 'a social representativeness' that have grown out of everyday language. ${ }^{r}$ As a source, they can therefore represent social groups other than those found in the skaldic poetry which were directed to rulers in the milieu of the hird, and thus primarily give knowledge of performances of the elite.

There are difficulties with analysis of place names, because several aspects of them must be considered. Place names are names of places, but Vikstrand points out that in the term 'place' you can distinguish three components: a geographical locality, a name, and a content that gives meaning to it. ${ }^{2}$ The relationship between these components is complicated and it is not always the given geographical location is the right one. For example, local people can ascribe place names an importance that they did not had during the time the researcher investigates.

In this part, the point of departure will be a few place names from mainly eastern Scandinavia and neighboring areas. These are examples of historical provinces in present Sweden, Finland, and Estonia that can provide information about hostages; a comparison is made with an example from Ireland.

In western Scandinavia, corresponding place names with 'hostage' as component do not appear. There are some problems with these place names: they may be mentioned in just one source, the place names are not contemporary, the etymology can be ambiguous,

How to cite this book chapter:

Olsson, S. 2019. Place Names. In: Olsson, S. The Hostages of Northmen: From the Viking Age to the Middle Ages. Pp. 225-249. Stockholm: Stockholm University Press. DOI: https://doi.org/Io.I6993/bba.e License: CC-BY. 
and the place names can indicate traditions that are not related to hostages. Below, however, a discussion of place names and their relationship with the common denominator 'hostage' is made.

\section{Gummi of Gislamark}

In the Gesta Danorum ('the Deeds of the Danes') by Saxo Grammaticus there is a place name that can be linked to hostage (Da. Gislemark, Sw. Gislamark) without ambiguity. The place name is described in Saxo's list of warriors from Svetjud (or Svealand) in the army of King Ring (or Sigurd Hring) at the battle of Bråvalla (OI. Brávellir). ${ }^{3}$ The battle - which in several texts is mentioned as the largest in Scandinavia in ancient times - has attracted interest from many researchers. From being regarded as a historical battle, it is now viewed as legendary, 'mythical', or merely devised. ${ }^{4}$ By 'legendary' I mean a story to which non-historical material was added. By 'mythical' I mean a possible reflection of myths. Saxo's list is attributed, for example, to the mythical, or legendary, character Starkad (ON Starkaðr, lat. Starcatherus); among other things, the battle has been perceived to be based on the Ragnarök theme or as a part of an IndoEuropean mythical heritage. ${ }^{5}$

I do not intend to take a position as to whether the battle took place or not, but just to analyse and relate to the list of names with the Swedes. In the Latin text it says:

At Sueonum fortissimi hi fuere: Ari, Haki, Keclu-Karll, Croc Agrestis, Guthfast, Gummi e Gyslamarchia. Qui quidem Frø dei necessarii erant et fidissimi numinum arbitri. ${ }^{6}$

The most valiant of the Swedes were: Ari, Haki, Keklu-Karl, Krok the Countryman, Guthfast and Gummi of Gislamark. Indeed, they were kinsmen of the divine Frø and faithful accessories of the gods. ${ }^{7}$

(Transl. Peter Fisher)

The name Gislamark would refer to a place where hostages would be used in a certain way (see further below). The modifer Gislawould then be derived to the Swedish gisslan 'hostage' and the head -mark to 'woodland' or 'field'. 
In the fragmentary Old Icelandic Sogubrot af fornkonungum (about I 300 ) there is a list that partially corresponds to Saxo's:

Pessir váru ofan af Svíaveldi: Nori, Haki, Karl kekkja, Krókarr af Akri, Gunnfastr, Glismakr goði. ${ }^{8}$

These came from above Svetjud: Nori, Haki, Karl kekkja, Krok of Akri, Gunnfastr, Glismakr goði.

(My free translation)

Instead of Gummi and Gislamark, Glismakr goði is mentioned. One can suspect that it is a rewriting by Saxo from 'Glismakr' to 'Gislamark', which has been Latinized to Gyslamarchia. ${ }^{9}$ But this can be easily explained. The personal name Glismakr, which is not a place name in the text of Sogubrot, cannot be confirmed by the text material of runestones or other sources. Possibly Glismakr can be a misconception, or rewriting, of the place name Glimåkra, the name of an old church town in the province of Skåne (or Scania), but if so is the case it is a matter of an entirely different region than Svetjud. ${ }^{\text {} 0}$ The philologist Axel Olrik pointed out in an article about the battle of Bråvalla that the author of Sogubrot in his list must have perceived goð $i$ as a sobriquet to Glismakr. Glismakr may be about Guði (OSw. Gudhi), but Olrik thought that it was about an 'unfortunate' corruption in the text of the name Gunni (Gummi) by an Icelandic writer. ${ }^{\text {II }}$ Even the list of the Sogubrot can be embroidered with learned elements even if it is less extensive than the version of Saxo.

Gesta Danorum was perhaps completed around I 208, while Sogubrot was fixed in writing about I 300 . However, Sogubrot can build on the Skjoldunga saga (from about I 80 ), which is now only found in some fragments and is considered to be based on the even older manuscript by Ari Porgilsson: conunga oevi. ${ }^{\mathrm{I2}}$

Both productions do not appear to have had the same prerequisites when it comes to the sources. Saxo's list of the warriors of the kings Harold Wartooth (or Harald Hildetand) and Ring is more detailed and could therefore be manipulated and supplemented by learned embroideries, to a greater degree than Sogubrot's version. Some of the names that appear can be explained as literary contributions, such as the presence of female warriors (amazons). 
Names like the alliterative Skale Scanius (as in the province of Scania) could have been added by Saxo just to include all the parts of the Danish realm of his own time. ${ }^{\mathrm{I} 3} \mathrm{He}$ may have also manipulated with the time and geographical conditions in the list of warriors. There are names of Jomsvikings who belongs to the I Ith century and not the eighth. ${ }^{14}$ As a medieval writer, Saxo may have had an interest in allegorically depicting the battle against the Vices: the Swedes is primarily described as idolatry worshipers. On the other hand, Saxo has generally been reassessed by several researchers. ${ }^{15}$ Everything is not literary inspiration and learned interpretations.

The historian Inge Skovgaard-Petersen considers the version of Gesta Danorum to be closer to the original than the list of Sogubrot. ${ }^{\text {I6 }}$ The historian Nils Blomkvist believes that the list of Saxo - in addition to having more names than Sogubrot - latinizes the names in order to 'improve them', but when it comes to the names of the Swedes, 'he makes hardly any adjustments at all'. ${ }^{17}$

However, there are no other evidence of Gummi of Gislamark in either Old Eastern Norse or Old Western Norse text sources. The personal name Gunni (or Gunne) is mentioned on 2 I rune stones in the province Uppland, while the name form Gummi (or Gumme) occurs on two. ${ }^{18}$ Gislamark (or Gislemark) does not exist as a place name in Uppland or in the Mälaren region. Gisslemark and Gilmark, on the other hand, are surnames in Sweden today. But the Swedish Institute for Language and Folklore (Sw. Institutet för språk och folkminnen) has no further information about these names in their collections. ${ }^{19}$ The theoretical possibility that remains is that the $16^{\text {th }}$-century editors of the Gesta Danorum manipulated the list; however, this is not likely.

Thus, it is not possible to determine whether the personal name of Gummi, with the place name Gislamark, have been inserted in a later stage, or if they stem from a possible older version for certain. But it is possible to relate to hypotheses about the origin of other place name with a similar meaning based on other source material. Through these place names, and the descriptions of them, the function of the hostage can be determined. 


\section{Gislamark and gisslalag}

Attempts have been made to find the origin of the place name Gislamark in text sources other than Gesta Danorum, which is linked to Finland and the Baltic countries. In A Description of the Northern Peoples (Sw. Historia om de nordiska folken, Lat. Historien de gentibus septentrionalibus) from I 555, by the Archbishop (in exile) Olaus Magnus, there is a list of the most important areas in the Nordic region. In this list Olaus Magnus mentions the place name Gislalagen (Lat. Gislemarchia). ${ }^{20}$

In the register of the I 976 edition, the ethnologist John Granlund identifies the Gislalagen with the medieval district called gisslalag (OSw. gislalagh), thus ascribe the area to Finland, which was a part of the Swedish realm between I 249 and I $809 .{ }^{21}$ The Gisslalag was a district where the inhabitants were obliged to pay taxes and a hostage was used as security. The inhabitants were also obliged to treat and accommodate the king and his retinue on visit. But the records are few for this territorial division from Finland, and they are found only in medieval texts. The earliest record is found in the Eric Chronicle (Sw. Erikskrönikan), which mentions how the Swedes abstained from I4 gisslalags to Novgorod (Russia) in the I 290 s after the founding of Viborg. ${ }^{22}$ The word is also found in the Treaty of Nöteborg from I323, according to which Novgorod abstained three gisslalags to Sweden (see Figure V.2). ${ }^{23}$ However, the place name need not only be ascribed to Finland.

The ethnologist Kustaa Vilkuna asscoiated the gisslalag (Fi. kiblakunta) as a place name, with Karelia (c.f. the Karelian place name Kihlakunta) and perceived it as an Eastern Finnish equivalent to the ancient Swedish districts of hundare and härad. He thus suggested that there should have been a similar former district division in Finland and Karelia. ${ }^{24}$ Any permanent country organization did not exist, but according to Vilkuna, Scandinavians could receive a tax from obsolete areas secured by the hostage. ${ }^{25}$

Vilkuna's hypothesis that the hostage may had its roots in an elderly institution in Finland or Karelia has been questioned by modern research. According to the historian Philip Line, there is no sustainable evidence before 1323 that these districts ever existed in Finland and Karelia. ${ }^{26}$ But Line ignores the information of the 


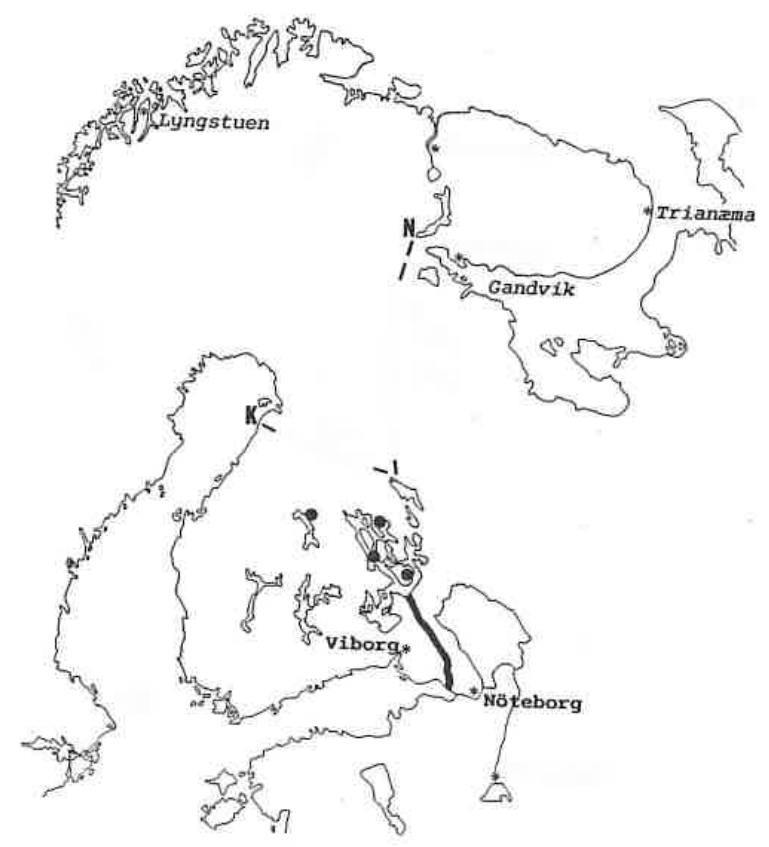

Figure V.1. Map of Finland including the medieval cities of Viborg and Nöteborg. Source: Sawyer \& Sawyer 1993: 68 (By permission from the authors, license CC BY 4.0).

Eric Chronicle, which can confirm that the gisslalag functioned as an organisational form in Finland in the I290s. Nevertheless, none of these text sources can actually tell you how old these traditions are. However, the place name of Kihlakunta may have been much older than the sources where it is recorded.

Vilkuna's statement that a 'king' would take hostages during the journey to the gisslalags with the implied threat that they would be executed - unless the king and his men received the food and drink they expected - must also be noted. This is not in line with the image of the hostage that is given in this book. The hostage was primarily used as a third party to ensure the safety of a person or a group. In this case it seems more probable that it was the king's person who should be secured. Food and other necessities were something that could still be taken through violence. Vilkuna also 
makes no difference between Finland, Karelia, Ingria, Estonia, and Courland. Different ruling powers had varying degrees of influence over these lands from time to time, which also meant that the use of hostages may have had different purposes.

Despite evidence from the medieval Finland, it is unclear whether an organisational form of gisslalag or equivalents ever existed in the 8 th-I Ith centuries, which can be confirmed by the place name Kihlakunta. However, the Estonian word kihelkond is of interest because there have been theories that it had a Scandinavian origin. Below, these theories and interpretations of the meaning of the word will be summarized.

\section{The districts of Kihelkond and syssel}

Vilkuna compared the Old Swedish word giszlalagh (alt. gislalagh) with the Finnish kiblakunta, the Estonian kibelkond, the Votic tshiblago and the Estonian-Finnish kunta. He indicated that the hostage institution in its time (the Middle Ages) stretched from the Livonian area of Courland across the Estonian-Votic area to the Southwestern Karelia. So, it was a matter of large areas. According to Vilkuna, the gisslalag was subject to a special 'food tax' or 'guest tax', which was collected in store houses. The food was provieded to the king and his retinue when he made visits. ${ }^{27}$ Vilkuna believed that hostages was taken as a security for the payment of the tax and if the tax was not paid, they were killed. Vilkuna also believed that the hostage institution could have existed even before the Middle Ages, something that could be seen through an example from Estonia. ${ }^{28}$

On the island Saaremaa ( $\mathrm{Sw}$. Ösel) there is a place called Kihelkonna, which can be deduced to the Estonian kihelkond, 'parish', a word that indicates a territory where the head -kond means 'area' and the modifier kibla- is a Nordic loan word (< OWN gísl, 'hostage', OE gisl 'hostage'). ${ }^{29}$ Vilkuna could support himself with other researchers who put forward the hypothesis of an ancient district of taxation in Estonia.

The historian Arvi Korhonen argued that smaller tax districts in Estonia already existed in the Viking age before the German 


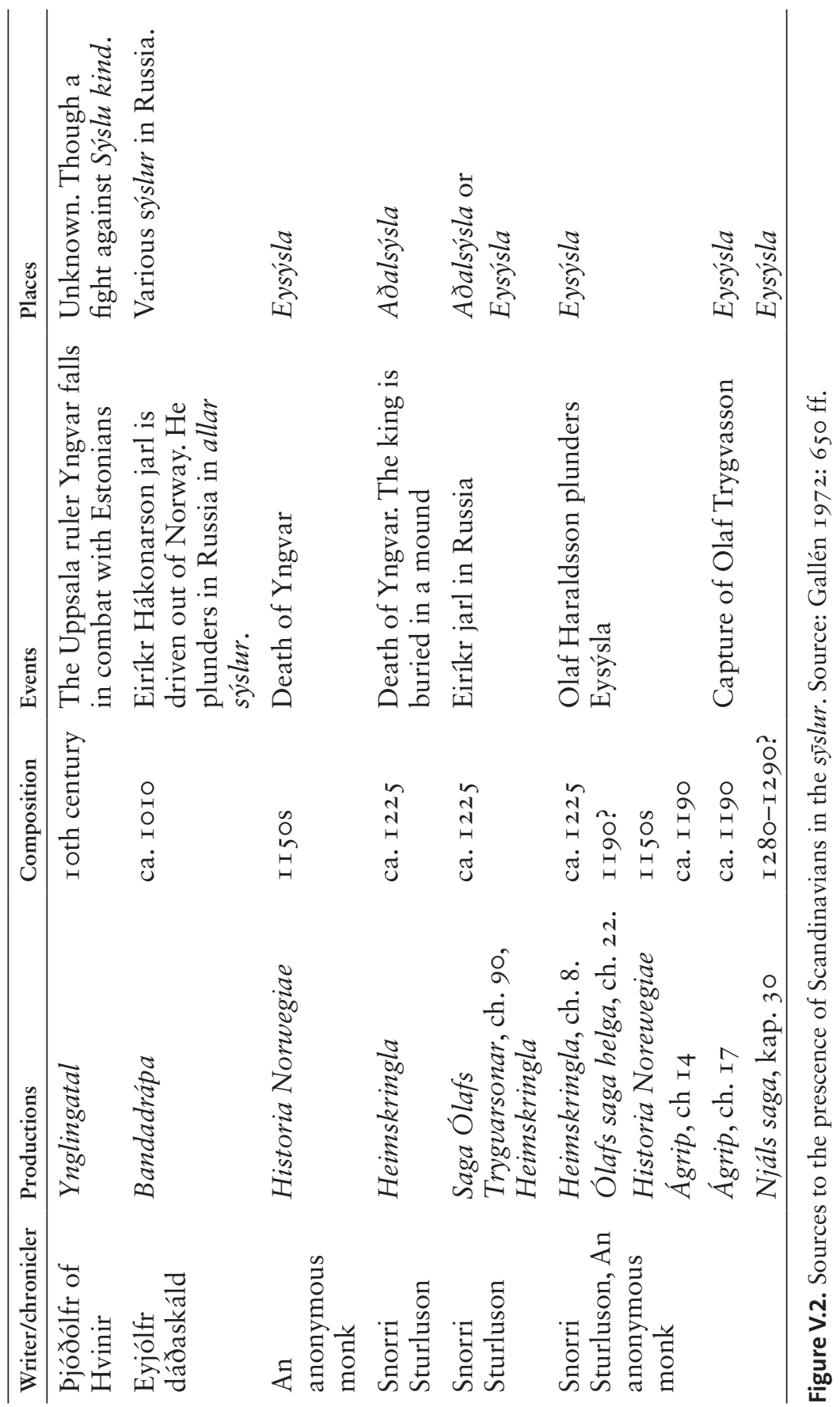


conquest in the $13^{\text {th }}$ century. The philologist Paul Johansen made a hypothesis of a territorial division in Estonia organized by Scandinavians. At Saaremaa (OI. Eysýsla, OGt. Oysl, Fi. Saarenmaa), a tax collection system would have been set up by Scandinavians already in the ninth century. ${ }^{3 \circ} \mathrm{A}$ model of the Estonian maa-names may also have originated in Scandinavian medieval names of districts. The syssels (ODan. syscel, OSw. sysel) were administrative units in the Middle Ages in Scandinavia. In addition, it can be argued that this district organisation in Jutland is considered - at least by an older generation of researchers - to be pre-Christian. ${ }^{3 \mathrm{I}}$

Johansen's interpretations, and Vilkuna's, have been questioned by the philologist Enn Tarvel. The modifier kibla- may be a Nordic loan word, but the meaning of the word in Estonian is, according to Tarvel, 'engagement', 'wooing quest', or 'engagement gift'. ${ }^{32}$ Only in the Livonian language is there a word that can be translated to 'pledge' or 'hostage' without ambiguity: $k \vec{\imath} l$. Tarvel mentions several reasons that a territorial division with the hostage as security should not have existed during the Viking Age and the early Middle Ages. In particular, he points to the importance of an extensive Scandinavian influence: 'Die Schaffung einer speziellen Besteuerung- und Geiselstellungorganisation würde ja doch eine längere skandinavische Oberherrschaft alls Verbindung notwendig machen'. ${ }^{33}$ According to Tarvel, the text sources are not convincing: the Ynglinga saga mentions Ivar Vidfamne (ON Ívarr inn víðfaðmi), or Erik Emundsson (ON Eiríkr Eymundsson) and the Danish Canute the Great as conquerors of Estonia which cannot be confirmed by other sources. ${ }^{34}$

It may not be certain whether the word 'hostage' in the sense that Tarvel claims really contradicts a hostage giving. The kunda-areas may have had this function in addition to those described by Tarvel. The philologist Urmas Sutrop believes that the head -kunta (alt. -kunda) is a loan word from the Germanic bunta (bunda) and may have occurred as early as in the Ioos AD, while the modifier kihl- may be (a younger?) loan word. 35 The modifier kibl-had several meanings: e.g. the word kiblused, 'wedding arrangement', and kihlvedu, 'bet', but kihlkonnad (alt. kihelkonnad) also have had the meaning of hostagegiving. ${ }^{36}$ Tarvel 
claims that an over-rule was required for the establishment of an administrative unit. In my view, a supremacy is not necessarily the prerequisite for an organization around the hostage. In Estonia and Courland, it has not been the question of a Scandinavian over-rule, but rather there have been different spheres of interest. This could be compared to the model for early medieval state formations presented in the introduction. Bagge's model applies primarily to Norway, but can be applied to other Viking communities. ${ }^{37}$ In these early pre-state societies, it was the personal ties that were decisive and that the local great men had to rely on. For example, such bonds may have been maintained by and the ambulatory rulership or kingship as described in the Kings' sagas and early medieval Nordic laws.

Regarding the development of a possible tax district organization in Estonia, it may initially, to a limited extent, have emerged without an early Scandinavian influence. According to Line, it could be the reason for the emergence of special fortresses (Est. Maalinnad) during the late Iron Age. These fortresses could dominate a territory which eventually became a kihelkond. ${ }^{38}$ Such fortresses belonged to a local elite. At the same time, these areas may occasionally have been in the sphere of interests of Novgorod and Kiev. The evidence for this to occur earlier than the I Ioos is vague, ${ }^{39}$ but the presence of the fortresses could indicate that these areas have periodically been subject to taxation - and perhaps hostage takings - from an external power. The establishment of fortresses in Estonia could also have been local defense measures against these charges, and the Kihelkond became an area subject to a local warrior elite. One possibility is that these districts were already organized when Viking raids, and later the crusades, were carried out by Scandinavians or other peopls.

Perhaps the Scandinavians perceived these areas as OSwe. sȳsla (pl. sȳslur), ON sýsla. If the word sȳsla ('county', 'district') is older than the Middle Ages, it can be related to the text sources that mention Scandinavian activities in the Baltic areas and on Saaremaa. The historian Jarl Gallén described the sources for where the ON word sysla is used as the designation of Saaremaa, which was the Old Norse Aðalsýsla..$^{\circ}$ The head -sýsla could be compared to the ancient Scandinavian district. 
The presence of Scandinavians in Estonia regarding plundering can be confirmed by several sources independent of each other (Figure V.I). Runic inscriptions also mention Scandinavians in Estonia, Livonia, and Courland. ${ }^{4 \mathrm{I}}$ There is archaeological evidence: Two boat graves dated to the eighth century have been found at Saaremaa near the village Salme. In the boat graves (Salme I-2) the archaeologists found in total 42 skeletons. In the boats there were also remains of grave goods such as pieces for board games, shields, arrowheads, swords, spears, hawks, dogs, and combs..$^{42}$ T. D. Douglas Price et al. state that the gravegoods suggest that the boat crews was on a diplomatic mission (perhaps an alliance with local chieftains on Saaremaa). Their analysis seems to confirm that the skeletons are of Scandinavian origins the tooth enamel is likely to descend from Scandinavia and the weapons are of Scandinavian design. ${ }^{43}$ The weapons are decorated with precious metals and garnets; there were also other luxuries as mentioned above, which, according to Price et al., make them suitable as gifts for political alliances. ${ }^{44}$ Price et al. also claim that there might have been a Scandinavian settlement on the Sõrve Peninsula of Saaremaa. ${ }^{45}$ They also have a hypothesis regarding the death of the warriors:

The shortest route from Courland to the 'mother country' in the Mälar district ran through the Salme straits. Noblemen from Denmark and the southern coast of the Baltic, along with the Götars [i.e. the Geats], wanted control of that route. It is entirely possible that the dead at Salme were the victims of an armed conflict between these foreign groups that left the Svear seafarers buried near the shoreline. Local Estonians need not have been involved in any way. ${ }^{46}$

Finally, there is an early source that confirms that Scandinavians took tributes and hostages in the Baltic region, that is, the case with Rimbert, whose biography of Ansgar (Vita Ansgari) describes how the Swedes received a hostage in 854 from the village of Apuole in Courland. ${ }^{47}$

The above may suggest that Scandinavians had a knowledge of taxation and hostages that they imposed on the Estonians and Courians. Whether or not the organizational form originated from 
Scandinavians or Germans (during the Middle Ages), was based on a domestic organization, or was established under the influence of powers such as Novgorod and Kiev, we can only speculate. Perhaps it was a combination of these forms.

During the peace negotiations between the inhabitants of Saaremaa and the invading armies (or raiding parties) that occurred during the crusades, the terms were dictated by the side that had the upper hand. For example, Valdemar II 'the Victorious' of Denmark tried to build a castle on Saaremaa in I 222. ${ }^{8}$ The Saaremaa islanders allied themselves with the Estonians and besieged the castle. After several days, the Danes and some Germans were invited to surrender with a promise of free passage if they left the castle and abandoned Saaremaa. After the Danes gave up, a hostage was taken, including a brother of the bishop of Riga, to consolidate the peace (obsides ibidem pro pacis confirmatone). ${ }^{49}$ A similar unilateral way of using hostages occurred several times after Christian victories over both islanders, Livonians and Estonians. ${ }^{5 \circ}$

The Estonian word kibelkond is certainly ambiguous, but it cannot be denied that the activity of the taking and giving of hostages as well as plundering occured. If the use of hostages was the result of a permanent organizational form during the Viking Age in the eastern part of the country, where Swedes carried out plundering, it could give more weight to the argument that the place name Gislamark - as produced by Saxo Grammaticus in the Gesta Danorum - can be derived from the Viking Age or earlier.

In addition to the examples from Nordic areas, a comparison can be made with an Irish place name that also occurs in - and may be the result of - various peace agreements: Airgíalla.

\section{Airgíalla in Ireland}

In Ireland, hostages have had functions within peace process that are mentioned in several sources. There is a place name that can be linked to the word for 'hostage' in Old Irish traditions called Airgíalla. According to one interpretation the place name might mean 'those who give hostages'. ${ }^{51}$ It was a federation of nine different people. 
Ireland traditionally had five major areas, 'fifths', or provinces, which were ruled by a provincial king (OIr. rí ruirech). The High King (ard-rí) had his seat in Tara, but this position was vague and existed only in theory because any permanent supremacy could not be consolidated. ${ }^{52}$ Individuals from different family-based groupings, clans, alternately held this position. For such groupings, genealogies were important to legitimise their power positions. ${ }^{53}$

The most powerful clan (or grouping) between the 6oos and the 900 in Ireland was called Uí Néill. They claimed their relationship with Niall Noigíallach. ${ }^{54}$ Connachta, another grouping, claimed to be descendants of the half-mythical High King Conn Cétchathach ('Conn of the Hundred Battles'). The territories of Connachta are named after them by the collective name Cúige Chonnact, 'Connachts Fifth'. According to the Book of Rights, Airgíalla would have matched the five major provinces and may have existed already in the fourth century.55 Perhaps this tribal federation was more likely to have arisen in the seventh century.

A dynasty of kings ruled Airgíalla; sometimes there was no provincial king, but two or three rival kings. It is possible that Airgíalla was dependent on the high kings in Tara. According to the legend, there were three kings, The Three Collas: Colla Óss, Colla Fochríth, and Colla Menn. These mythical or legendary figures may have given rise to Airgíalla after defeating a number of Irish tribal federations, including ulaid, a people in the historic province of Ulster. ${ }^{56}$

The status of Airgíalla in relation to the five major provinces (fifths) is disputed. It is possible that their rulers' genealogies cannot be linked to Connachta or Uí Néill at all. Other individual dynasties within Airgíalla, such as the dynasty Mugdorna, suggest that the federation was founded in the seventh century. It is likely that the dynasty Colla Óss was one of the most important dynasties because it is mentioned in $\mathbb{S} 8$ of The Airgíalla Charter Poem. ${ }^{57}$

An etymological explanation of the name *Airgíallne, is that the morpheme -ne, was confused with an abstract suffix, -(ai) $n e$, and was supposed to be a diversion of giall(n)ae, 'service' or 'base clientship'. The name Airgíall(n)ae was thus considered to 
mean 'additional clientship'. Another interpretation suggests that *Airgiallnai, with the head -giallnae of OI giallae, are comparable to the Latin dicio and deditio. ${ }^{8}$ The -giallnae could also be derived to giall, 'hostage', 'security'.59

The earliest reference to Airgíalla that can be confirmed is found in the Annals of Tigernach (year 677), which also reproduces a ruler - Dúnchad Mac Ultán ('son of Ultán') - who would be 'king' of Airgíalla (Ri Oigirall), but this information is uncertain. The Annals of Ulster of the year 697 describes the ruler Máel Fothartaig Mac Máel Dub ('son of Maeldub') as 'Rex na nAirgialla'.60 Because Máel Fothartaig and his son Eochu Lemnae are mentioned as guarantors of the Law of Adomnáñan from the 70os, the information about him as a ruler in Airgíalla can be genuine. ${ }^{61}$

In 704 there was a battle between the king of Connacht, Cellach Mac Rogallaig, belonging to a dynasty called Uí Briúin, and Loingsech Mac Óenguso who was rex Hiberniae, 'King of Ireland' and ruler of Tara, who belonged to the Cenél Conaill, a branch of the Uí Neill-dynasty. In the list of people fallen in the battle, Eochu Lemnaes and Fergus Forcraid are found. These belonged to two clans, called Uí Chremthainn and Uí Thuirtri. ${ }^{62}$ These groups were allied with Uí Néill. Several alliances between the dynasties of Airgíalla and Uí Néill also occurred before this battle. According to the historian Edel Bhreatnach, Airgíalla was probably a military federation. ${ }^{63}$ This is confirmed by a further list of dead from a settlement between two warlords. In 743, Domnall defeated Midi, who belonged to the clan Chlomain Áed Allán of the Cenél federation, who were allied with Airgíalla. ${ }^{64}$ Thus, it was alliances and counter alliances over an area of confrontation.

\section{The Airgíalla Charter Poem}

The earliest written source which gives information about the foundation Airgíalla is The Airgíalla Charter Poem. According to Bhreathnach, there were two main events underlying the creation of the document: (a) the relationship between the dynasties that founded or formed Airgíalla; and (b) the formal definition of the relationship between the dynasties called Arigíalla and Uí Néill. ${ }^{65}$ 
According to the Celtologist Thomas M. Charles-Edwards, the agreement was thought to be a way of defining the relationship to Uí Néill, and the agreement should have been to Airgíalla's advantage. ${ }^{66}$ In The Airgialla Charter Poem, in $\mathbb{S}$ I I there is a reference to Áed Allán, which is interpreted by Bhreathnach: An alliance has existed between the Cenél federation and Airgíalla between 722 and $743 .{ }^{67}$ The Airgialla Charter Poem might have been composed at this time.

The poem is divided into four sections with amendments (added articles). These amendments were a result of several different negotiations. The first section, according to Charles-Edwards, is a historical prologue that deals with the land areas and genealogical relationships between Airgíalla and Uí Néill. In the second section, article I4, the case of hostages is mentioned.

I4. Ar-dlegat íarara co neuch ar-da-gíalla ar-dlegat fiadnaise it clethe for fíadna.
I4. They are entitled to demands together with anyone who gives them hostages. ${ }^{68}$

(Transl. Edel Bhreathnach \& Kevin Murray)

Article $\mathrm{I}_{4}$ is about the rights of the Five Kindreds ( Na cóic clanda) of Uí Néill vis-à-vis Airgíalla, the same rights they used, according to Charles-Edwards, against all their subject territories. The hostage that Airgíalla gave the Five Kindreds is not specified in this context. The article may also be interpreted so that Airgíalla had certain rights (demands) in the same way as other territories that were subordinated to Uí Néill and were hostage givers. ${ }^{69}$

I 8. Ar-dlegat a forbanda

a suidiu fhlatho acht ma ar-da-gíallatar i rroï chatho.
I 8. They are entitled to their extra exactions from the seat of a ruler unless hostages are given to them on the field of battle. ${ }^{70}$

(Transl. Edel Bhreathnach \& Kevin Murray)

$\mathbb{S}$ I 8 belongs to the same section of The Airgialla Charter Poem as $\mathbb{I} 4 \cdot^{71}$ It could be interpreted that Airgíalla was to share the 
requirements (exactions), or privileges, that a ruler (of the Five Kindreds) could impose on a defeated enemy unless they could take hostages themselves on the battlefield.

\section{Dlegair donaib}

Airgíallaib córus a ngíallnae slóged trí cóicthiges dïa téora blíadnae.
23. There is due to from the

Airgíalla the proper arrangement of their hostageship, a hosting of three fortnights every three years. ${ }^{72}$

(Transl. Edel Bhreathnach \& Kevin Murray)

The next section of The Airgialla Charter Poem is about the obligations of Airgíalla regarding military service. An obligation called slógad, 'hosting', which meant that an army formed through an alliance or agreement could pass through the territory of Airgíalla. $\mathbb{2} 23$ is difficult to interpret, but in the translation of Bhreathnach and the philologist Kevin Murray, there is a word, ngíallnae, which they interpret as 'hostageship'. ${ }^{73}$ The article is about the obligation to accommodate troops, but what is meant by 'hostageship' is unclear in this case. If Aírgíalla were to make war with other federations, it was necessary with what we today refer to as 'diplomacy'. ${ }^{74}$ If an army, in allegiance with Aírgíalla, passed through their territory, they would travel via pre-selected roads and would camp at certain places as specified in $\mathbb{2} 2$.

28. Cumal cacha forbaise fessar co slógib acht manis túissed eolach dia ndúnaib córib.
28. A cumal for every camp which spends the night with hosts, unless a knowledge able person should conduct them to their proper encampments. ${ }^{75}$

(Transl. Edel Bhreathnach \& Kevin Murray)

The following can be interpreted from this: a representative of the visiting army would stay with the hosts overnight at every place they camped, unless a person well-known in Aírgíalla was responsible for their conduct. This person, who represented an area, would probably be valued after his rank. 
The last section of the poem leans towards two agreements that should have been made during the sixth century between Aírgíalla and Uí Néill. In this section, mythical elements are included in the text that will guarantee peace. $\mathbb{S} 40$ claims that authorities which might be percieved as deities - like the 'sea and land with they sky, sun and moon' will guarantee that the peace will be maintained. ${ }^{76}$ The next article (4I) mentions 'Dew and light, God's apostles from heaven, aged men, prophets, patriarchs and bright angels'. ${ }^{77}$ Several researchers argue that these are examples of how Christian and pre-Christian traditions occur side by side..$^{7}$

Another article (46) mentions hostages as a security for the agreement. They are called aitiri, 'hostage sureties'.

46. It sruithi a n-aitiri do-chuitchetar már [...].
46. Their hostage sureties are venerable men who have sworn mightily [...].

(Transl. Edel Bhreathnach \& Kevin Murray) 79

According to Charles-Edwards, aitiri was used as a guarantee for major public agreements between two or more túathas. The article also shows that the hostage could swear oaths; thus they had a 'legal capacity'. In The Airgíalla Charter Poem, much of what is described in previous chapters occurs. Although the proposed etymologies of the place name Airgialla (or Airgiallnae) are uncertain, Bhreathnach and Murray believe that the word forms the basis for the federation's relationship to Uí Néill: 'airgíallnae suggests the tentative translations "additional hostageship" or "additional service". ${ }^{80}$ Certainly, Airgíalla was subordinated to Uí Néill, but their strength ensured that they could not be totally subjected to other dynasties. Different types of contracts were established because of peace settlements in which hostages served as a security or regulatory factor in the areas of confrontation, but in different ways. The hostage was therefore not only linked to warlike activities but also peace times, something that could be related to my hypothesis about the 'available hostage'. The invocation of mythical elements, both pre-Christian and Christian, as security for peace shows the specific connections to the giving of 
\begin{tabular}{lll}
\hline The Airgialla Charter & Examples of cases & Part \\
Poem & &
\end{tabular}

(I) A hostage

with different purposes that is at disposal.

(2) Myths and legends about hostages.
In 877 . The Great Heathen

III. p. $84 \mathrm{ff}$. Army gave hostages to Alfred. In 994. The hostage provided by III. p. 9I ff. Æthelred to Olaf Tryggvason. In the $3^{\text {th }}$ century. The giving of the hostages of the Geats VI. p. $25 \mathrm{I}$ ff. to the king in the province of Västergötland.

The Æsir-Vanir War.

II.

The legends about Vikar and Walther.

IV. p. $158 \mathrm{ff}$.

Semilegendary: The death of

Ragnvald Knaphövde in I I 30 .
(3) Disputed land areas.

(4) Oaths.

Security.

In the 8 th to Ioth centuries.

Negotiations between Danish rulers and the Carolingian royal power. Likewise between Danish and Saxon rulers.

The Orkney Islands in the early I I th century. Clashes between competitive earls.

The Gislalags in Finland in the I 3 th century.

V. p. $226 \mathrm{ff}$.

In 878 . The peace processes between Alfred and Guthrum.

Early Ioth century. The oath of Earl Brusi Sigurdsson to Olaf Haraldsson.

Gisla and grutha in the medieval Swedish laws.

(5) Morality and consequences.

Various litterary examples:

Vikar and Herthjóf, Walter and Attila.

The Æsir-Vanir War.

(6) The social value of hostages.
The value of female hostages.

IV. p. I $60 \mathrm{ff}$.

Conduct and loyalty.

IV. p. I $57 \mathrm{ff}$. The Æsir-Vanir War.

Figure V.3. Comparsion between different text sources regarding rituals. 
hostages. In this settlement legal, religious, and economic aspects presuppose each other.

There are several other points in The Airgíalla Charter Poem that can be compared to what has been found in this study, Figure V.3.

The Irish examples are interesting from a comparative perspective, although it is not possible to translate the political conditions of the sixth and seventh centuries of Ireland into the Old Norse conditions. In order to emphasize these altering conditions, the hostage giving and taking that is described in the Elder Westrogothic Law in the following part will be analysed. The purpose is to describe the power political situation that was specific to this particular area at the time of the law's accession.

\section{Concluding remarks}

In this section, some place names are analyzed that may be connected with hostages. Saxo Grammaticus states in Gesta Danorum a list of warriors from Sweden (or Svetjud) before the mythical or legendary battle of Bråvalla. The list contains name of Gummi from Gislemark (Gummi e Gyslamarchia). The place name (gisl-, 'hostage') would - although not without some ambiguity - point to a ground where a hostage was used in peace negotiations.

In the Icelandic Sogubrot af fornkonungum, the name list is reproduced with Swedish warriors before the battle of Bråvalla, but instead of Gummi Glismakr, goð $i$ is mentioned. This is a personal name and not a place name, which cannot be confirmed by other sources; that it would be a rewriting of the old church village Glimåkra in Scania is far-fetched. Both the authors of Gesta Danorum and the Sogubrot appear to have had access to partly the same source material. Both works show signs of learned work, and when it comes to Saxo's list of Swedish warriors, Nils Blomkvist believes that Saxo hardly makes any changes at all in relation to the source material. There is no other evidence other than Saxo's list that mentions Gummi from Gislemark in Uppland, Mälardalen, or any other parts of the ancient Svetjud. It is, however, not possible to determine with certainty whether the person name Gummi and the place name Gislemark was included in an 
earlier version of the story about the battle Bråvalla or is a later addition by Saxo.

A hypothesis has been put forward about the possible place name Gislamark. In Olaus Magnus's A Description of the Northern Peoples mention is made of the place name Gyslamarchia, which Granlund places in Finland, and he believes that it is a rewrite of the medieval districts called gislalaghs. These districts are mentioned in sources including The Eric Chronicle (Swe. Erikskrönikan) and the treaty of Nöteborg (1323). These were districts obliged to pay taxes to the Crown, who used a hostage as a security for the delivery. Kustaa Vilkuna has claimed that an even older district that preceded the gislalaghs. These ancient districts would correspond to the Swedish hundare ('hundred'). This has been rejected by later research because it is only described in late-medieval text sources. The hypothesis that Gyslamarchia in Saxo's list may correspond to the gislalagh is therefore uncertain.

Another place name that may be of interest in these contexts is Kihelkonna at Ösel. The Estonian name Kihelkond (or kiblkon$n a d)$ is a word for a territory where the main path, -con, can mean 'area' and the decision path, Kihle-, can have the possible meaning 'hostage'. However, the philologist Enn Tarvel points out that the word is ambiguous in the Estonian language and can mean both 'hostage' and 'engagement, freedom travel'.

Another place name that may be of interest in these contexts is Kihelkonna at the Island of Saremaa (Swe. Ösel). The Estonaian Kibelkond is a word for a territory in which the head could mean 'area' and the modifer, Kihel-, can have the possible meaning 'hostage'. The philologist Enn Tarvel points out that the word is ambiguous in the Estonian language and can mean both 'hostage' or 'engagement, wooing quest'.

The tax district organization in Estonia may have arisen in connection with the establishment of special fort (maalinad) during the late Iron Age that may have evolved into kiblekond. However we can only speculate on, the advent of these districts, but the existence may imply that an organizational form was established that the Scandinavians could utilize even as early as during the Viking Age. The presence of Scandinavians in the Baltic lands is stated in the saga literature, in runic inscriptions, and in the 
biography of Ansgar, which states how the Swedes received hostages from the city of Apuolè.

One can compare this with the Irish place name Airgíalla, which could have the meaning 'those who give hostage'. It was a tribal federation that corresponded to the great provinces of Ireland. They had a special relationship to the dominant clan (or grouping) called Uí Néill.

The earliest source depicting the foundation of Airgíalla is The Airgialla Charter Poem. The Poem, probably written between 722 and 743 , addresses the relationship between the dynasties who founded Airgíalla and their relationship with Uí Néill. In the poem, which is divided into four sections, there are five paragraphs, which mention hostages in different contexts. In a section, heathen deities are also listed alongside God, prophets, patriarchs, and angels as guarantors of peace. A paragraph also shows that the hostage had a legal capacity by being able to bear witness by oath.

Although the etymology of the place name Airgíalla is uncertain, Edel Bhreathnach and Kevin Murray indicate that a possible translation may be 'additional hostageship'. The Airgialla Charter Poem shows that hostages were an important part of the regulation of the relationship between Airgíalla and Uí Néill and that they were thus linked not only to wartime activities but also to peace time, something that can be related to the hypothesis of a hostage that was available. The Airgialla Charter Poem contains many points that can be compared to what has been disccused about place names above.

\section{Notes to Part V}

I. Vikstrand 200I: 33 .

2. Vikstrand 200I: I9.

3. Saxo Grammaticus, Gesta Danorum = Danmarkshistorien I ([ed.] Friis-Jensen): 5I I-5 I7 (Book 8, Ch. I, I-3, I3).

4. See N. Blomkvist 2005: $240 \mathrm{ff}$. 
5. E.g. Skovgaard-Petersen I987: I79 ff.; Wikander I960.

6. Saxo Grammaticus, Gesta Danorum = Danmarkshistorien I ([ed.] Friis-Jensen): 5 I 6 (text), (Book 8, Ch. 3, II).

7. Saxo Grammaticus, The History of the Danes ([ed.] Hilda Ellis Davidson): 240 (Book 8).

8. Sogubrot af fornkonungum (Danakonunuga sogur [(ed.) Bjarni Guðnasson]: 64 [Ch. 8]).

9. Müller I 823: I 22.

Io. According to the Svenskt ortnamnslexikon the place name Glimåkra can be traced to the late I 4 th century. The head, *Glima-, is probably aimed at the river Glimån (Svenskt ortnamnslexikon 20I6: 98).

I I. Olrik I 894: 253.

I2. Finnur Jónsson I920-24: 828; Friis-Jensen 1987: 23; N. Blomkvist 2005: $240 \mathrm{f}$.

I3. Skovgaard-Petersen 1987: 262.

I4. N. Blomkvist 2005: 242.

I 5. See Saxo og Snorre (2010).

I6. Skovgaard-Petersen I987: 262.

I7. N. Blomkvist 2005: 249.

I 8. Peterson 2007: $90 \mathrm{ff}$.

I9. E-mail Agneta Sundström, research archivist, Swedish Institute for Language and Folklore.

20. Olaus Magnus, Historia [...] (transl. Granlund): 3 I 5 .

2I. Granlund I976: 543 .

22. Erikskrönikan ([ed.] Jansson): 73.

23. Gallén \& Lind I99I: 3I4; Tarvel I998: I93, I98, n. I; N. Blomkvist 2005: 264 .

24. Vilkuna 1964: 9-30. 
25. Vilkuna I960: 9-30, 328.

26. Line 2009: 79 .

27. Vilkuna I960: 328.

28. Vilkuna I960: 328 .

29. de Vries I977: I68; Tarvel I998: I93; c.f. Sutrop 2004: 52.

30. Vilkuna I960: 328 .

3I. The Philologist Troels Dahlerup (I960: 649) considers that the Danish traditions of the syssels is older than the time for the introduction of Christianity. In Norwegian context, the syssel tradition means 'activity', 'work', or 'purpose' and may possibly be earliest recorded in connection with the activities of the king's solicitor in the 900s and Iooos (Andersen I960: 645). The earliest mention of the syssel in Iceland is the law code Jónsbók ([ed.] Schulman): I9 (I, 7); 30 (III, 2); 330 (VIII, 26) from about I270-I280 and the syssel could therefore be connected to the traditions of the Icelandic law (Björn Porsteinsson I960: 648).

32. Tarvel I998: 193.

33. Tarvel I998: I94.

34. Tarvel I998: I94.

35. Sutrop 2004: 5I.

36. Sutrop 2004: 5I.

37. See Part I.

38. Line 2009: 79 .

39. See Line 2009: 79.

40. Gallén I972: $650 \mathrm{f}$.

4I. See Peterson 2007: 3 I I, 3I 7, 32 I, 323 f.

42. Curry 20I3: 24 ff.; T. D. Price et al. 20I6: I026 f.

43. T. D. Price et al. 2016: I030 ff.

44. T. D. Price et al. 2016: 1033. 
45. T. D. Price et al. 20I6: I033 f.

46. T. D. Price et al. 2016: I035.

47. See Part IV.

48. Livländische Chronik / Chronicon Livoniae ([ed.] Alb. Bauer): 280 b. (text), 28I b. (Ch. 26, 2)

49. Livländische Chronik / Chronicon Livoniae ([ed.] Alb. Bauer): 280 f. (text), 28 I f. (transl.) (Ch. 26, 2).

50. See Kala 2009: I69-I90.

5 I. F. J. Byrne I973: 73; Cróinín 2004: 202.

52. Jaski 2005: 253 .

53. See O'Rahilly I946: 225 ff.; Jaski 2005: 253.

54. P. Byrne 2005: $489 \mathrm{f}$.

55. Se J. F. Byrne I973: 47.

56. J. F. Byrne I973: 47; Bhreathnach 2005: 95 .

57. J. F. Byrne I973: 46; Bhreathnach 2005: $95 \mathrm{f}$.

58. O'Rahilly I946: 224; Bhreathnach 2005: 95.

59. Dinneen I927: 534 .

60. See Bhreathnach 2005: 96.

6I. Bhreathnach 2005: 96.

62. Bhreathnach 2005: $97 \mathrm{f}$.

63. Bhreathnach 2005: 98.

64. Bhreathnach 2005: 98.

65. Bhreathnach 2005: 96.

66. Charles-Edwards 2005: 100.

67. Bhreathnach 2005: 98.

68. The Airgialla Charter Poem: Edition, The Kingship and Landscape of Tara ([ed.] Bhreathnach \& Murray): I30 (text), I3 I (transl.).

69. C.f. Charles-Edwards 2005: IOI, II7. 
70. The Airgialla Charter Poem: Edition, The Kingship and Landscape of Tara ([ed.] Bhreathnach \& Murray): I32 (text), I33 (transl.).

7I. Charles-Edwards 2005: IOI.

72. The Airgialla Charter Poem: Edition, The Kingship and Landscape of Tara ([ed.] Bhreathnach \& Murray): I32 (text), I3 I (transl.).

73. The Airgialla Charter Poem: Edition, The Kingship and Landscape of Tara ([ed.] Bhreathnach \& Murray): I32 (text), I32 (transl.).

74. Charles-Edwards 2005: Io0.

75. The Airgialla Charter Poem: Edition, The Kingship and Landscape of Tara ([ed.] Bhreathnach \& Murray): I34 (text), I35 (transl.).

76. The Airgialla Charter Poem: Edition, The Kingship and Landscape of Tara ([ed.] Bhreathnach \& Murray): I36 (text), I37 (transl.).

77. The Airgialla Charter Poem: Edition, The Kingship and Landscape of Tara ([ed.] Bhreathnach \& Murray): I3 8 (text), I39 (transl.).

78. See Charles-Edwards 2005: I22; Bhreathnach \& Murray 2005: I 55 , n. 4O-I.

79. The Airgialla Charter Poem: Edition, The Kingship and Landscape of Tara ([ed.] Bhreathnach \& Murray): I 38 (text), I39 (transl.).

80. Bhreathnach \& Murray 2005: I40, n. Ib. 
